\title{
SOME APPLICATIONS OF PHYSICOCHEMICAL ANALYSIS IN PHARMACY
}

\author{
L.D.Grytsan
}

National University of Pharmacy

Key words: physicochemical analysis; fusion diagram; boiling diagram; mutual solubility diagram of liquids; binary system

After a brief review of the basic ideas and principles of the method of physicochemical analysis, its advantages and drawbacks, a number of its applications in pharmaceutical science and technology has been considered. The diagrams of fusion, boiling and liquid mutual solubility are of the most interest. When developing the technologies for manufacturing novel medicines the plotting and geometric analysis of phase diagrams for model binary systems allow to optimize the processes of crystallization, rectification, etc., in which phases are separated.

Till the end of the 19-th century the preparative me thod was the main one for studying chemical systems. Its essence consists in extracting of the given substance from the system by means of crystallization, distillation, etc., followed by the study of its composition and properties. This method is used extensively up to now, especially in organic chemistry. However, to study solutions, melts and other complicated systems by the preparative method appeared to be insufficient. A novel method for studying multi-component systems was developed on the basis of the theory of the chemical equilibrium and was named "physicochemical analysis". The aim of the present article is to give a brief review of the fundamentals of the method of physicochemical analysis and its significance for pharmacy $[2,5,7,8]$.

The founder of physicochemical analysis as an independent scientific discipline is considered to be N.S.Kurnakov [6]. He carried out theoretical and experimental studies in this field and proposed the term "physicochemical analysis" (1913). Its essence consists in consideration of the dependence of the physical properties of the system in equilibrium on the factors that determine it. A significant contribution to development of this field of research was made by D.I.Mendeleev, J.H. van 't Hoff, G.Tammann, H.Le Chatelier, D.P.Konovalov, V.F.Alekseev, V.Ya.Anosov, Ya.G.Goroshchenko, A.V.Novosyolova, Yu.Ya.Fialkov, V.M.Valyashko and other scientists $[1,3,4,9-11]$.

Two basic principles formulated by N.S.Kurnakov are the basis for physicochemical analysis:

1. The essence of the correspondence principle consists in attributing a certain geometric image on the phase diagram to each set of phases existing in equilibrium in the given system according to the Gibbs phase rule. It is this principle that allowed N.S.Kurnakov to define physicochemical analysis as a geometric method of studying chemical transformations.

2. The continuity principle asserts that if the parameters determining the state of the system vary continuously, the properties of its phases also vary continu- ously. If the number of phases changes, the properties of the system also change; as a rule, they change abruptly.

Depending on the nature of the system under consideration its heat, as well as electric, optical, mechanical and other characteristics are experimentally determined. Based on the experimental data the phase diagrams in the "physical characteristics - equilibrium factor" (e.g., pressure, temperature, composition) coordinates are plotted. All chemical processes that occur when any equilibrium factors change, such as formation and/or disintegration of chemical compounds, formation and disappearance of solid and/or liquid solutions, etc., are expressed as geometric changes of surfaces, lines and points constituting a diagram.

Geometrical analysis of such diagrams allows to judge on the character of the interaction between the components of the system, the possibility of forming chemical compounds, their number and composition, to determine the existence domains and compositions of equilibrium phases without actual separation of the components of the system. Therefore, this method can be applied to the objects that cannot be studied by classical preparative methods. Limitations of physicochemical analysis lie in that its application allows to find whether chemical transformations occur in the system, but cannot determine their causes and mechanisms.

Initially physicochemical analysis was used to the systems in equilibrium. Practical application of this method to the synthesis of novel compounds using irreversible reactions in non-equilibrium systems led also to consideration of "characteristics - composition" diagrams for such systems.

Application of modern numerical methods gives the possibility to obtain the analytical expression for the function that describes the dependence of a physical property on the system composition without the experiment and to plot the phase diagram or its parts. By using such a diagram it is also possible to obtain additional data, for instance to calculate the degree of dissociation of a chemical compound from the curvature of the liquidus line. 
The phase diagrams plotted in the "physical characteristics - the system composition" coordinates are of the most interest. Thus, for plotting phase diagrams it is helpful to choose such physical characteristics that are sensible to the change of the system composition, for instance melting temperature, heat capacity, electric conductivity, index of refraction, density, viscosity, surface tension and others. In modern physicochemical analysis the number of properties used makes up to several dozens.

Plotting and analysis of the phase diagrams underlie many technological processes, in particular crystallization, rectification, extraction, etc., i.e. those in which phases are separated.

For pharmaceutical science and technology the phase diagrams for binary systems are of the most importance. To plot them as the physical property it is customary to choose the melting temperature (crystallization), boiling (condensation), clearing (turbidity). Analysis of the phase diagrams describing the processes of melting (crystallization), boiling (condensation) and the mutual solubility of two liquids promotes the optimization of technological operations of chemical and pharmaceutical, perfume and cosmetic industry, and biotechnological production. Application of the method of physicochemical analysis allows to increasing the product yield and reducing the energy consumption. For analytical purposes, it is preferable to choose such a property that additively depends on the composition of the system. Therefore, the important preliminary stage of the study is in the appropriate choice of the physical property and ways of expressing concentrations of the system components. In some cases in order to increase reliability of the results it is necessary to consider and compare measurements of several properties. Phase diagrams are also used in pharmaceutical analysis for identification and determination of the purity degree of medicinal substances and excipients.

Plotting and analysis of fusion diagrams of binary systems of medicinal substances allows to reveal their physical and chemical incompatibility, and it is important when developing technologies for manufacturing novel dosage forms and medicines.

It is known that physical incompatibility is related to formation of the eutectics. For instance, anesthesin and resorcine, antipyrine, and phenacetin form eutectic mixtures. Dampening can be already observed in the process of preparation of a dosage form. This is explained by the fact that the melting temperature of the eutectic mixture is much lower than the melting temperatures of pure components. At the same time, formation of eutectic mixtures can result in improvement of the drug quality.
The eutectic mixture consists of finer particles than the mixture of the same substances, but of the composition differing from the eutectic one. It leads to the uniform distribution of components in a dosage form. Besides, bioavailability of poorly soluble medicinal substances increases in eutectic mixtures with decrease of the particle size. Liquid dosage forms composed of eutectic mixtures of medicinal substances are also applied in dentistry.

Chemical incompatibility of medicinal substances related to the interaction of components resulting in the synthesis of novel compounds can be studied using fusion diagrams.

In pharmaceutical technology the plotting and analysis of fusion diagrams of model binary systems are also used:

- for determining the composition of mixtures (thermal analysis);

- in choosing the best method of extraction from mixtures and purification of medicinal substances;

- when studying the existence of several polymorphous modifications of medicinal substances for further study and comparison of their therapeutic action;

- when determining the aggregate state of the mixtures of components with a definite composition at the temperature that is of practical interest;

- when studying the mutual solubility of solid- and liquid-state components;

- in choosing the optimal dispersity of components.

Boiling diagrams of the binary liquid mixtures with unbounded mixing constitute the theoretical basis of the fractional distillation used both in pharmaceutical analysis and technologies of the production and purification of pharmaceutical substances, and in the design of novel dosage forms and medicines. Boiling diagrams are also used for selection of the optimal conditions of regeneration of certain components of liquid mixtures that are wastes of the manufacturing processes of medicinal substances.

Phase diagrams of the binary liquid systems with restricted solubility plotted in the "clearing (turbidity) temperature - composition" coordinates at $p=$ const find an application in pharmaceutical practice for determination of the composition of dosage forms that should not laminate during the storage.

\section{CONCLUSIONS}

Taking into account the importance of physicochemical analysis for pharmaceutical science and technology the topic under consideration in the course of physical and colloid chemistry deserves the appropriate attention. When teaching this topic to students of all pharmaceutical specialties one of the primary goals is to form their practical skills in plotting and analyzing phase diagrams.

\section{REFERENCES}

1. Аносов В.Я., Озерова М.И., Фиалков Ю.Я. Основы физико-химического анализа. - М.: Наука, 1976. - 503 с.

2. Беляев А.П., Кучук В.И., Евстратова К.И. и др. Физическая и коллоидная химия. - М.: ГЭОТАР-Медиа, 2010. - 704 c.

3. Валяшко В.М. Фазовые равновесия и свойства гидротермальных систем. - М.: Наука, 1990. - 270 с. 
4. Горощенко Я.Г. Физизко-химический анализ гомогенных и гетерогенных систем. - К.: Наукова думка, 1978. $-490 \mathrm{c}$.

5. Кабачний В.І., Грицан Л.Д., Томаровська Т.О. та ін. Фізична та колоїдна хімія. - Х.: НФаУ ; Золоті сторінки, 2015. - 432 с.

6. Курнаков Н.С. Введение в физико-химический анализ. - М.-Л.: Изд-во АН СССР, 1940. - 564 с.

7. Ландау Л.Д., Лифиии Е.М. Статистическая физика. Ч. 1. - М.: Наука, 1976. - 584 с.

8. Лебідь В.І., Гричан Л.Д. Фізико-хімічний аналіз / В кн.: Фармачевтична енциклопедія. II вид. - К.: Моріон, 2010. - C. 1481-1482.

9. Новосёлова А.В. Фазовые диаграммы, их построение и методы анализа. - М.: Изд-во Моск. ун-та, 1987. $-152 c$.

10. Фиалков Ю.Я. Двойные жидкие системы. - К.: Техніка, 1969. - 220 с.

11. Фиалков Ю.Я. Физико-химический анализ жидких систем и растворов. - К.: Наукова думка, 1992. - 245 с.

\section{ДЕЯКІ ЗАСТОСУВАННЯ ФІЗИКО-ХІМІЧНОГО АНАЛІЗУ В ФАРМАЦІЇ}

\section{Л.Д.Грицан}

Ключові слова: фозико-хімічний аналіз; діаграма плавкості; діаграма кипіння; діаграма взаємної розчинності рідин; бінарна система

Після короткого огляду основних ідей та принципів методу фрізико-хімічного аналізу, його переваг і недоліків розглянуто низку застосувань методу в формацевтичній науці та технологіях. Найбільший інтерес представляють діаграми плавкості, кипіння та взаємної розчинності рідин. При розробці технологій виробництва нових лікарських препаратів побудова та геометричний аналіз фразових діаграм бінарних модельних систем дозволяє оптимізувати процеси кристалізації, ректифрікації та ін., в яких відбувається розділення фаз.

\section{НЕКОТОРЫЕ ПРИЛОЖЕНИЯ ФИЗИКО-ХИМИЧЕСКОГО АНАЛИЗА В ФАРМАЦИИ \\ Л.Д.Грицан}

Ключевые слова: фризико-химический анализ; диаграмма плавкости; диаграмма кипения; диаграмма взаимной растворимости жидкостей; бинарная система

После краткого обзора основных идей и принципов метода физико-химического анализа, его достоинств и недостатков рассмотрен ряд приложений метода в фрармацевтической науке и технологиях. Наибольший интерес представляют диаграммы плавкости, кипения и взаимной растворимости жидкостей. При разработке технологий производства новых лекарственных препаратов построение и геометрический анализ фразовых диаграмм бинарных модельных систем позволяют оптимизировать процессы кристаллизации, ректифрикации и др., в которых происходит разделение фраз. 